dissipation of heat from the surface. The authors' experiments show that by putting a 6 in. metal disc above the conical shade of a 60 watt lamp, the final steady temperature was reduced from $57 \cdot 5^{\circ}$ to $23^{\circ} \mathrm{C}$. With a 200 watt lamp in a 14 in. enclosed bowl and canopy, the temperature rise was $83 \cdot 5^{\circ} \mathrm{C}$. By removing the domed top of the canopy, replacing it by a flat metal disc 6 in. in diameter, putting the holder mainly outside the canopy, placing a disc in the base of the canopy, putting a mica disc in the lamp and using a moulded holder, the temperature rise was only $23^{\circ} \mathrm{C}$.

\section{Microscope Technique}

THE current issue of the Journal of the Royal Microscopical Society (vol. 53, pt. 1) contains Mr. Conrad Beck's presidential address on microscope illumination, which should be read for its useful observations on the substage condenser in relation to the objective. In the same issue Dr. P. Gray summarises and classifies in convenient form the methods of fixation of animal tissues which have been found most successful for different purposes, and Mr. D. P. Wilson describes a simple and inexpensive apparatus for trimming paraffin blocks, which can be used upon a Cambridge rocking micro. tome and will be found particularly useful for trimming small blocks so as to ensure a straight ribbon of sections when the block is being cut.

\section{International Congress of Anthropological and Ethnological Sciences}

Arrangements are well forward for giving effect to the decision of the international conference held in Basel recently (see NAture of May 20, p. 719) that an International Congress of the Anthropological and Ethnological Sciences should be established and that the first meeting should be held in London in 1933. It has now been decided that the session will take place on July 30-August 4, 1933. An executive committee will be responsible for the preparations for the Congress. At a meeting of the Royal Anthropological Institute held on July 4, Capt. T. A. Joyce was elected chairman of the Executive Committee, Mr. H. Beazley, treasurer, and Prof. J. L. Myres and Mr. Alan H. Brodrick, joint honorary secretaries with Mr. Adrian Digby as assistant secretary. Accommodation for the meetings of the Congress offered by University College, London, and the Wellcome Historical Medical Museum, has been accepted provisionally.

\section{Announcements}

Prof. F. Paneth, formerly director of the Chemical Institute of the University of Königsberg, has recently been elected a foreign honorary member of the American Academy of Arts and Sciences, Boston.

Dr. W. L. BALLs, director of the Botanical Section, Ministry of Agriculture, Egypt, has been appointed cotton technologist to the Ministry of Agriculture,
Egypt. Dr. J. Templeton has been appointed director of the Botanical Section in succession to Dr. Balls. Dr. Templeton has been in the service of the Egyptian Government since 1921, prior to which he was a lecturer in the Botanical Department of the University of Edinburgh.

Mr. A. Jones has recently been appointed by the Secretary of State for the Colonies to be assistant superintendent of agriculture, Gold Coast.

The British Pharmaceutical Conference will be held on July 24-28 in London, with its headquarters. at Grosvenor House, Park Lane, W.1. The president. of the Conference will be Mr. John Keall, president of the Pharmaceutical Society of Great Britain. Some thirty papers of scientific interest will be presented and a discussion will be held on the Pharmacy and Poisons Act, 1933. Further information can be obtained from the Secretary, Pharmaceutical Society of Great Britain, 17, Bloomsbury Square, London, W.C.1.

IN the article entitled "Plaice Fishery of the North Sea" (NAture, July 1, p. 35, par. 5), the following sentence appears: "In both England and Holland, too, a considerable industry is said to exist in supplying small fish to fish meal and fertiliser factories." This is incorrect. Miss D. E. Thursby-Pelham in her "Report on the English Plaice Investigations during the Years 1926 to 1930 ", on which the article was based, refers to "Germany and Holland". In Germany this industry is very considerable, whereas in England it is practically non-existent.

Applications are invited for the following appointments, on or before the dates mentioned :-An assistant in the Mining Department of the North Staffordshire Technical College-The Clerk to the Governors, Education Offices, Town Hall, Hanley, Stoke-on-Trent (July 17). A lecturer in mechanical engineering at the Rutherford Technical College, Newcastle-upon-Tyne-The Director of Education, Education Office, Northumberland Road, Newcastleupon-Tyne, 2 (July 20). A lecturer in the Department of Physiology and Biochemistry at University College, Gower Street, London, W.C.1-The Secretary (July 21). A full-time lecturer in mechanical engineering at the Leeds Technical College-The Director of Education, Education Offices, Calverley Street, Leeds (July 24). A head of the Engineering Department of Cheltenham Technical College-The Secretary (July 24). A director of the Warrington Museum-The Clerk to the Committee, The Museum, Warrington (July 31). A teacher for workshop processes of printing on textiles and a teacher for the design of woven fabrics in the School of Applied Art, Giza, Egypt-The Director, Egyptian Education Office, 39, Victoria Street, London, S.W.1 (Aug. 10). An assistant lecturer in applied mathematics at University College, Swansea-The Registrar (Sept. 5). A lecturer in psychology at King's College of Household and Social Science, Campden Hill, London, W.8-The Secretary. 